\title{
Seasonality and timing of peak abundance of Aedes albopictus in Europe: Implications to public and animal health
}

\author{
Mina Petrić, ${ }^{1}$ Els Ducheyne, ${ }^{1}$ Céline M. Gossner, ${ }^{2}$ Cedric Marsboom, ${ }^{1}$ Gaëlle Nicolas, ${ }^{1}$ \\ Roger Venail, ${ }^{1}$ Guy Hendrickx, ${ }^{1}$ Francis Schaffner ${ }^{3}$ \\ ${ }^{1}$ Avia-GIS, Zoersel, Belgium; ${ }^{2}$ European Centre for Disease Prevention and Control, Solna, Sweden; \\ ${ }^{3}$ Francis Schaffner Consultancy, Riehen, Switzerland
}

\begin{abstract}
Aedes albopictus is a known vector of dengue and chikungunya. Understanding the population dynamics characteristics of vector species is of pivotal importance to optimise surveillance and control activities, to estimate risk for pathogen-transmission, and thus to enhance support of public health decisions. In this paper we used a seasonal activity model to simulate the start (spring hatching) and end (autumn diapause) of the vector season. In parallel, the peak abundance of the species was assessed using both VectorNet field survey data complemented with field studies obtained from literature across the Mediterranean Basin.

Our results suggest that spring hatching of eggs in the current distribution area can start at the beginning of March in southern Europe and in April in western Europe. In northern Europe, where the species is not (yet) present, spring hatching would occur from
\end{abstract}

Correspondence: Guy Hendrickx, Avia-GIS, Risschotlei 33, 2980 Zoersel, Belgium.

E-mail: ghendrickx@avia-gis.com

Key words: Invasive mosquitoes; vector activity modelling; vectorborne diseases; temperature; photoperiod.

Acknowledgements: this work is based on the technical report delivered as part of the contract OC/EFSA/AHAW/2013/02-FWC1 between AVIA-GIS, the European Centre for Disease Prevention and Control and the European Food Safety Authority. We thank all people contributing to VectorNet by providing mosquito distribution data and contributing to the field surveys.

Contributions: MP and ED contributed equally to the manuscript.

See online Appendix for additional materials.

Received for publication: 7 December 2020.

Revision received: 8 March 2021.

Accepted for publication: 8 March 2021.

(C) Copyright: the Author(s), 2021

Licensee PAGEPress, Italy

Geospatial Health 2021; 16:996

doi:10.4081/gh.2021.996

This article is distributed under the terms of the Creative Commons Attribution Noncommercial License (CC BY-NC 4.0) which permits any noncommercial use, distribution, and reproduction in any medium, provided the original author(s) and source are credited. late April to late May. Aedes albopictus can remain active up to 41 weeks in southern Europe whilst the climatic conditions in northern Europe are limiting its potential activity to a maximum of 23 weeks. The peak of egg density is found during summer months from end of July until end of September. During these two months the climatic conditions for species development are optimal, which implies a higher risk for arbovirus transmission by $A e$. albopictus and occurrence of epidemics.

\section{Introduction}

The Asian tiger mosquito Aedes (Stegomyia) albopictus (Skuse, 1894) (Diptera: Culicidae) is recognised as an alien invasive arthropod species of major importance (Medlock et al., 2015).

Globally, Ae. albopictus is considered as a potential vector for a range of pathogens driving vector-borne diseases of public and/or animal health importance (e.g. chikungunya, dengue, Japanese encephalitis, Zika, Rift Valley fever and West Nile viruses, as well as Dirofilaria filarial nematodes) (Schaffner et al., 2013; McKenzie et al., 2019). In mainland Europe, the species is considered to be the main vector of dengue and chikungunya viruses. Sporadic events of dengue and chikungunya virus transmissions, but also Zika (Giron et al., 2019), have been described since 2007 in Croatia, France, Italy and Spain (ECDC, 2017; ECDC, 2019b; ECDC, 2020a).

Over the last decade, through the VectorNet project, the European Centre for Disease Prevention and Control and the European Food Safety Authority have been collecting presence/absence and abundance data using standardised protocols, either actively through field surveys (ECDC \& EFSA, 2018a) or passively via literature reviews of scientific reports and peer-reviewed journal articles. One of the outputs is the production of biannual maps of confirmed presence/absence of invasive and native mosquito species, which are published on ECDC website (ECDC, 2020b).

Temperate strains of Ae. albopictus have developed reproductive diapausing as a convenient form of phenotypic plasticity, allowing the overwintering of pharate larvae in temperate regions and supporting its invasion of more northern latitudes (Hawley, 1988; Lacour, 2016).

Whilst the presence of Ae. albopictus is well documented and closely followed in Europe, the seasonality (start and duration of the season of activity) and abundance of the species is less studied. Understanding these characteristics of population dynamics is of critical importance in order to improve vector monitoring 
and control operations, to contribute to the assessment of the risk of transmission of pathogens and, thus, to strengthen support for public health decisions. The change in abundance of a species over the year is referred as seasonality, one or more abundance peaks and decline in population size may occur over a single year. These repetitive fluctuations in time are driven by external factors such as seasonal variations in temperature and photoperiodicity.

Local scale field studies (Medlock et al., 2006; Roiz et al., 2010) provided important insights on the impact of climatic variables and supported the development of local-scale mathematical models (Baldacchino et al., 2017). However, a broader-scale analysis of Ae. albopictus seasonality is lacking. A first step was made by ECDC (2009) in which a series of continental maps indicating the start of season as determined by egg hatching was presented. Abundance modelling at a continental scale was later carried out by Caminade et al. (2012), Erguler et al. (2016) and Metelmann et al. (2019).

ECDC \& EFSA (2018b) highlighted the difficulties of abundance monitoring and their implication to public and/or animal health. Season and seasonality can vary from year to year and be influenced by a variety of environmental and anthropological factors such as climate, vegetation and host availability. The most relevant abiotic variables appear to be temperature, photoperiodicity, and precipitation, for which threshold values have been estimated in a number of surveys in Asia (Nawrocki \& Hawley, 1987; Kobayashi et al., 2002), the Americas (Nawrocki \& Hawley, 1987; Swanson et al., 2000) and Europe (Knudsen et al., 1996; Toma et al., 2003).

The temperature threshold for establishment of Ae. albopictus populations is considered to be an annual mean temperature of $11^{\circ} \mathrm{C}$ (Kobayashi et al., 2002). The optimal temperatures at which the population can proliferate are between 15 and $35^{\circ} \mathrm{C}$; below these temperatures reduced mobility and longevity are observed (Hylton, 1969; Brady et al., 2013). Mean January temperatures and total annual precipitation have been found to limit the winter survival of diapausing eggs in the northern hemisphere, with egg mortality increasing significantly if temperatures are below $0^{\circ} \mathrm{C}$ (Nawrocki \& Hawley, 1987; Kobayashi et al., 2002) and precipitation is below $500 \mathrm{~mm}$ (Kobayashi et al., 2002). In temperate areas, the timing of the production of diapausing eggs in autumn and their subsequent hatching in spring are mainly determined by temperature and photoperiod (Focks et al., 1994; Hawley, 1988).

Medlock et al. (2006) assumed spring hatching to start when i) spring temperature exceeds $10.5^{\circ} \mathrm{C}$; and ii) photoperiod exceeds $11.25 \mathrm{~h}$. Female activity is observed to stop in autumn (diapausing) when temperature goes below $9.5^{\circ} \mathrm{C}$ and photoperiod below $13.5 \mathrm{~h}$. Assuming an increase in temperature in the short to medium term, climate change is expected to support the development of non-diapausing populations of Ae. albopictus in the Mediterranean Basin (Collantes et al., 2014). Continuous egg-laying has already been observed in southern Spain and Italy (Collantes et al., 2014; Bonacci et al., 2015). Lacour (2016) suggests that this adaptive selection is likely directed by the advantage to expand its period of activity but may be also linked to the suppression of a cost of diapause (Scheiner, 1993). All these factors make the exact prediction of the start and end of the activity season of the species over a larger area complex as local smallscale environmental and climate factors could strongly influence its seasonality and peak of abundance.

This main goal of this paper is to present updated seasonality maps of Ae. albopictus in Europe: i) the timing and length of the annual peak in abundance; ii) the expected start of spring hatching; iii) and the expected number of active weeks leading to autumn diapause. The aim is to provide information on the main seasonal characteristics for Ae. albopictus in order to inform European public health and animal health authorities about the risk of arbovirus transmission and support authorities in their vector control activities.

\section{Materials and methods}

\section{Seasonality}

The spring and autumn thresholds for weekly photoperiod and temperature governing the seasonality of Ae. albopictus were searched in literature, as well as annual precipitation and temperature influencing the climatic suitability for vector overwintering and establishment. The review was carried out using PubMed and Embase. The screening was focused on peer-reviewed research and review papers describing Ae. albopictus seasonality and establishment thresholds. The search string for updating the climatic thresholds was run on the $21^{\text {st }}$ of January 2021. Non-primary studies were excluded and only papers in English were included.

Following this, the spatially explicit seasonality model from Medlock et al. (2006) was adapted using the threshold values inferred from literature. The mean of the extracted values was retained as the optimal value for the climatic threshold and standard error was calculated to report the uncertainty. Normality was first assessed using the Shapiro-Wilk test (Ghasemi \& Zahediasl, 2012), for parameters that did not assume a normal distribution bootstrapping was utilised to calculate the uncertainty. The model was validated on data from the VectorNet database.

First, a suitability mask was generated excluding areas that did not meet the necessary climatic and environmental constraints. The first criterion is based on precipitation, the second on the mean January temperature. The minimal annual precipitation and mean January temperature were derived from the ERA5 Land database (CCCS, 2019). An area was classified as suitable if the rainfall was higher than $422 \mathrm{~mm}$ and the mean January isotherm higher than $-3.0^{\circ} \mathrm{C}$.

Second, within the suitable areas, spring hatching and autumn diapause were determined on a weekly basis. The ERA5 Land (CCCS, 2019), hourly, 2-meter air temperature was used to generate 7-day mean temperatures. The photoperiod was calculated using the meteor R-package (Hijmans, 2019) for every latitude for the last day of the 7-day composite.

The start of spring hatching was then defined as soon as the mean weekly temperature exceeded $10.6^{\circ} \mathrm{C}$ and the photoperiod exceeded 11.2 hours. Similarly, the start of autumn diapause was defined as soon as the mean weekly temperature was lower than $10.4^{\circ} \mathrm{C}$ and the photoperiod lower than $13.3 \mathrm{~h}$. The spring hatching and autumn diapause maps were then used to calculate the expected annual activity window.

The model uses a simple conditional statement to capture the week in which the thresholds for spring hatching and autumn diapause are met. The annual activity is calculated as the difference between these two dates. The calculations are run on a $0.1^{\circ} \times 0.1^{\circ}$ grid. The model was first validated against the current distribution (presence/absence) of Ae. albopictus in Europe for 2019 (ECDC, 2019a). This was done using the area under the ROC curve (AUC) 
score and the True Skill Statistic (TSS). The AUC score ranges in value from 0 to 1 , and defines the probability that a randomly chosen positive example will be ranked higher than a randomly chosen negative example. An AUC score $>0.5$ indicated that the model is performing better than random, while a score of 1 indicates perfect prediction. The TSS statistic ranges from -1 to 1 , where 1 indicates perfect agreements and values less than 0 indicate a performance no better than random. Both the AUC score and the TSS statistic have been shown to be independent of prevalence (Allouche et al., 2006). In a second step, the dates generated by the seasonal activity model were compared against longitudinal VectorNet field data collected from 5 locations in Greece in 2017. Validation was not performed for the year 2020 because ERA5 temperature data is updated monthly with a delay of approximately 3 months relative to the current date (CCCS, 2019), and would thus prevent a full record for 2020 .

\section{Abundance}

Over the last decade several population models have been created for Ae. albopictus for the USA (Erickson et al., 2010) and for Europe (Poletti et al., 2011; Caminade et al., 2012; Tran et al., 2013; Erguler et al., 2016; Baldacchino et al., 2017; Metelmann et al., 2019; Wint et al., 2020), with some having explicit references to environmental conditions (Erguler et al., 2016). All models focused on local abundance levels with the exception of Erguler et al. (2016) which tried to extrapolate the method developed to Europe, but the output represents an index of mosquito habitat suitability instead of abundance.

Given the lack of data that might be used in a pan-European model, field studies reported in literature were examined to obtain local seasonality and abundance profiles to complement data collected under VectorNet. The time series representing the egg density versus the week were analysed for the reported literature using the metagear v0.4 package (Lajeunesse, 2016). The significant peaks were identified using the pracma v2.1.4 package (Borchers, 2019).

\section{Results}

\section{Climatic thresholds}

In total 59 full text papers were screened, of which 31 were retained. The results indicated that thresholds both for overwintering as well as spring hatching and autumn diapausing as defined by Medlock et al. (2006) should be adjusted. In total 133 values were extracted for: mean January temperature (14); total annual precipitation (13); mean weekly temperature (6) and photoperiod (5) conducive to spring hatching; and mean weekly temperature (4) and photoperiod (91) conducive to autumn diapause. The updated threshold estimates are presented in Table 1. Please see the supplementary material (S1) for a more detailed overview of the literature review.

In Asia, overwintering of diapausing eggs occurs where mean January temperatures are lower than $-2^{\circ} \mathrm{C}$ (Kobayashi et al., 2002) or even $-3^{\circ} \mathrm{C}$ and $-4^{\circ} \mathrm{C}$ (Nawrocki \& Hawley, 1987; Wu et al., 2011). In Europe Waldock et al (2013) suggested to use a $4^{\circ} \mathrm{C}$ isotherm, while in the USA a threshold of $-5^{\circ} \mathrm{C}$ was suggested (Khan et al., 2020). Tippelt et al. (2020) specify that the vector is capable of overwintering at temperatures $<2{ }^{\circ} \mathrm{C}$ in Europe.

Even though the cut-off for total annual precipitation of 500 mm was previously reported for Europe (Knudsen et al., 1996; Medlock et al., 2006), Proestos et al. (2015) suggested that a lower threshold should be used for Ae. albopictus, since it has been consistently confirmed to be established in areas with $<500$ $\mathrm{mm}$ annual precipitation (Eritja et al., 2005; Waldock et al., 2013).

No studies reported spring hatching at temperatures $<10^{\circ} \mathrm{C}$. Spring hatching was reported to occur with weekly temperatures between $10^{\circ} \mathrm{C}$ to $15^{\circ} \mathrm{C}$ and photoperiods between $11 \mathrm{~h}$ and $12 \mathrm{~h}$ (Medlock et al., 2006; Romi et al., 2006; Takumi et al., 2009; Gatt et al., 2010; Mogi \& Tuno, 2014; Flacio et al., 2016). Autumn conditions triggering diapause were reported to occur when weekly temperatures go below $12.5^{\circ} \mathrm{C}$ to as low as $9^{\circ} \mathrm{C}$, and photoperiods from $14 \mathrm{~h}$ to $11.2 \mathrm{~h}$ (Focks et al., 1994; Toma

Table 1. Climatic thresholds governing the overwintering, establishment, spring hatching and autumn diapause of Aedes albopictus.

\begin{tabular}{|c|c|c|c|}
\hline & Climatic parameter & Value & Literature \\
\hline 1 & $\begin{array}{l}\text { Mean January temperature } \\
\text { limiting overwintering }\end{array}$ & $-3.0 \pm 0.46\left[{ }^{\circ} \mathrm{C}\right]$ & $\begin{array}{l}\text { (Nawrocki \& Hawley, 1987; Kobayashi et al., 2002; Medlock et al., 2006; Wu et al., 2011; } \\
\text { Neteler et al., 2013; Waldock et al., 2013; Ogden et al., 2014; Proestos et al., 2015; } \\
\text { Kuhlisch et al., 2018; Petri et al., 2018; Khan et al., 2020; Tippelt et al., 2020) }\end{array}$ \\
\hline 2 & $\begin{array}{l}\text { Total annual precipitation } \\
\text { limiting establishment }\end{array}$ & $422 \pm 32[\mathrm{~mm}]$ & $\begin{array}{l}\text { (Knudsen et al., 1996; Eritja et al., 2005; Medlock et al., 2006; Takumi et al., 2009; Roiz et al., } \\
\text { 2011; Neteler et al., 2013; Waldock et al., 2013; Ogden et al., 2014; Proestos et al., 2015; } \\
\text { Cunze et al., 2016; Kuhlisch et al., 2018; Sherpa et al., 2019; Khan et al., 2020) }\end{array}$ \\
\hline 3 & $\begin{array}{l}\text { Critical temperature } \\
\text { for spring hatching }\end{array}$ & $10.6 \pm 0.36\left[{ }^{\circ} \mathrm{C}\right]$ & $\begin{array}{l}\text { (Medlock et al., 2006; Romi et al., 2006; Takumi et al., 2009; Gatt et al., 2010; Mogi \& Tuno, } \\
\text { 2014; Flacio et al., 2016; Komagata et al., 2017) }\end{array}$ \\
\hline 4 & $\begin{array}{l}\text { Critical photoperiod } \\
\text { for spring hatching }\end{array}$ & $11.2 \pm 0.24[\mathrm{~h}]$ & $\begin{array}{l}\text { (Medlock et al., 2006; Romi et al., 2006; Takumi et al., 2009; Gatt et al., 2010; Flacio et al., } \\
\text { 2016) }\end{array}$ \\
\hline 5 & $\begin{array}{l}\text { Critical temperature } \\
\text { for autumn diapause }\end{array}$ & $10.4 \pm 0.65\left[{ }^{\circ} \mathrm{C}\right]$ & (Medlock et al., 2006; Takumi et al., 2009; Mogi \& Tuno, 2014; Pasquali et al., 2020) \\
\hline 6 & $\begin{array}{l}\text { Critical photoperiod } \\
\text { for autumn diapause }\end{array}$ & $13.3 \pm 0.06[\mathrm{~h}]$ & $\begin{array}{l}\text { (Focks et al., 1994; Toma et al., 2003; Medlock et al., 2006; Lacour et al., 2015; Tsunoda et al., } \\
\text { 2015; Armbruster, 2016; Erguler et al., 2016; Xia et al., 2018; Pasquali et al., 2020) }\end{array}$ \\
\hline
\end{tabular}


et al., 2003; Medlock et al., 2006; Takumi et al., 2009; Lacour et al., 2015; Tsunoda et al., 2015; Armbruster, 2016; Erguler et al., 2016; Xia et al., 2018; Pasquali et al., 2020).

\section{Seasonality}

The start of the spring hatching of eggs for 2019 (Figure 1) shows a very clear gradient from south to north. Around the Mediterranean Basin, spring hatching is expected to occur as early as week 8, corresponding to late February. More northwards, in most of Western Europe, hatching is expected to occur six to eight weeks later, from early to mid-April.

In areas where the species is currently not observed (Figure 2), such as in Scandinavia and Scotland for example, spring hatching could potentially occur in week 16-25 if Ae. albopictus was to establish itself there.

Some areas in e.g. Spain and Italy do not have any spring hatching week predicted, because of insufficient rainfall.
However, this can be compensated by human-generated water, which is not included in the model. Looking at the potential weeks of activity (Figure 3), we see that the longest period of activity can be found in the Mediterranean Basin going from 39 to 43 weeks.

This means that in this region, the season can potentially start from end of February and run until mid-November, yielding four to six generations within a single vector season (Kobayashi et al., 2002). At higher altitude and where the species is not yet present, the number of potential weeks of activity could potentially reach 23 weeks.

The performance of the model in reproducing the observed distribution of Ae. albopictus in Europe for 2019 (Figure 2) was validated with an AUC score of $0.89(\mathrm{P}<0.0001)$ and TSS statistic of 0.68 , indicating good performance. The observed end-ofactivity in Greece in 2017 was in week 44, showing fairly good correspondence with the simulated onset of diapause (week 43).

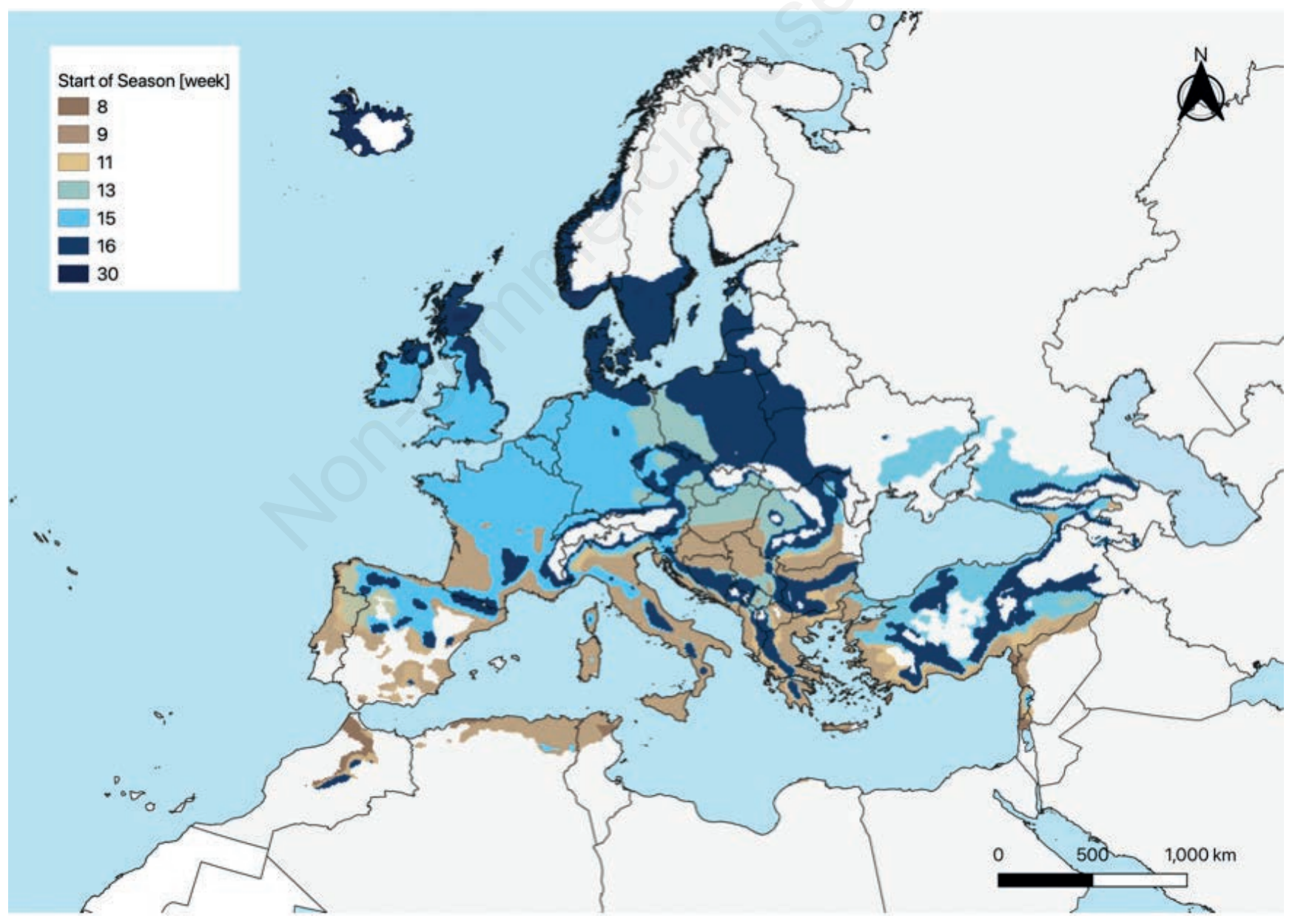

Figure 1. Potential mean week of start of spring hatching of Aedes albopictus for the VectorNet area for 2019, with first adults appearing ca. 2-4 weeks later. Colours show the range of activity start, from early (dark brown) to late (dark blue) start. White areas are the masks from temperature and precipitation. Country boundaries are downloaded from Natural Earth. Free vector and raster map data @naturalearthdata.com. 


\section{Peak of abundance}

Observed egg peak timing, with week number if this was reported, and the size of the peak are shown in Table 2. In general, the peak of abundance is reached over summer, but the actual timing when the peak is reached varies spatially and temporally according to the prevailing eco-climatic variables. In southern Europe, the abundance curve of the species increases rapidly from end of June and will decrease by November in a unimodal situation. The seasonal dynamic patterns analysed by Manica et al. (2016) and resulting from field survey outputs of VectorNet in Italy showed, however, a bimodal pattern (with a peak of abundance in August and another one in October) which is consistent with field observations in the city of Rome. The first peak was temperature-driven whilst an unusual amount of rainfall in September seems to be a major driver of the second peak in midOctober. When temperatures and photoperiod became sub-optimal for the species, a rapid decrease of the abundance was found despite frequent rainfall. A bimodal seasonal dynamic pattern with host-seeking mosquito abundance would prolong the potential transmission season in suburban areas.

\section{Discussion}

The main aims of this study were to present updated maps capturing the seasonality of Ae. albopictus in Europe. The results indicate that the total number of weeks between spring hatching and autumn diapause is expected to be over 34 weeks around the Mediterranean Basin, from 12 to 28 weeks in the UK, and would be 12 to 23 weeks in northern Europe if the mosquito was to be established there.

The biggest difference with the continent-wide analysis performed by ECDC (2009) is the inclusion of areas which were previously deemed as unsuitable for establishment such as Germany, Switzerland, Austria and parts of Eastern and Northern Europe. In their study for the UK, Medlock et al. (2006) calculated the maximum number of weeks of activity to be 24 weeks, corresponding to the southern country border, and no activity for the area along the border with Scotland. This important difference might be due to a combination of the update of the thresholds, inter-annual temperature differences and increase of temperature compared to the 1971-2000 period (Kendon et al., 2020), affecting the start and end of the season. Medlock et al. (2006) did not provide an output for their model at the more

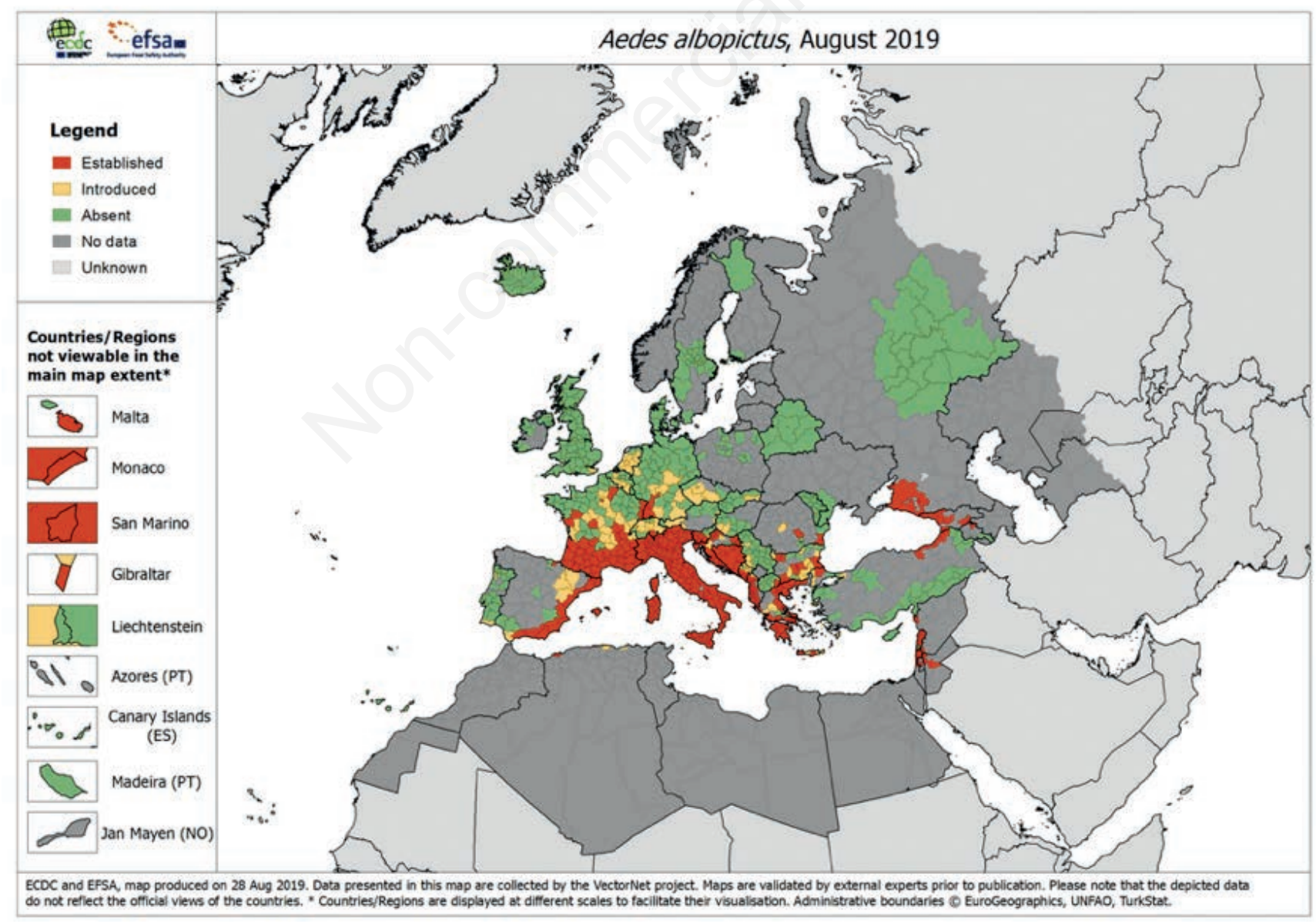

Figure 2. Current known distribution of Aedes albopictus in Europe by 2019 (ECDC, 2019a). Source: ECDC. 
Table 2. Timing and size of expected Aedes albopictus egg abundance peak by country.

\begin{tabular}{|c|c|c|c|}
\hline Country & Egg peak timing (week number) & Size of peak & Reference \\
\hline Croatia & $\begin{array}{l}\text { End of July/Early August (w 30-31) } \\
\text { Early September (w 34-35) }\end{array}$ & $\begin{array}{l}\text { Major } \\
\text { Major }\end{array}$ & (Žitko \& Merdić, 2014) \\
\hline Greece & $\begin{array}{l}\text { September (w 35-40) } \\
\text { November (w 48) }\end{array}$ & $\begin{array}{l}\text { Major } \\
\text { Minor }\end{array}$ & (Giatropoulos et al., 2012) \\
\hline \multicolumn{4}{|l|}{ Italy } \\
\hline Central (Lazio) & $\begin{array}{l}\text { End of August (w 35) } \\
\text { October/November (w 44) }\end{array}$ & $\begin{array}{l}\text { Major } \\
\text { Minor }\end{array}$ & (Manica et al., 2016; Toma et al., 2003) \\
\hline South (Calabria) & $\begin{array}{l}\text { Mid-July } \\
\text { August } \\
\text { Mid-September }\end{array}$ & $\begin{array}{l}\text { Major } \\
\text { Minor } \\
\text { Major }\end{array}$ & (Bonacci et al., 2015) \\
\hline South (Sicily) & $\begin{array}{l}\text { End-July/Early August } \\
\text { Late August } \\
\text { Mid-September }\end{array}$ & $\begin{array}{l}\text { Minor } \\
\text { Major } \\
\text { Major }\end{array}$ & VectorNet database \\
\hline France (south) & $\begin{array}{l}\text { Late June-early July (w 27) } \\
\text { End of August (w 33) }\end{array}$ & $\begin{array}{l}\text { Major } \\
\text { Major }\end{array}$ & (Lacour et al., 2015; Tran et al., 2013) \\
\hline Switzerland (south) & Mid-August (w 34-35) & Major & (Flacio et al., 2016; Suter et al., 2016) \\
\hline $\begin{array}{l}\text { Spain } \\
\text { North East (Catalonia) } \\
\text { South East (Murcia) } \\
\text { Balearic Island of Majorca }\end{array}$ & $\begin{array}{l}\text { July-early September (w 29-37) } \\
\text { Late August-October (w 35-43) } \\
\text { Early September-October (w 37-43) }\end{array}$ & $\begin{array}{l}\text { Major } \\
\text { Major } \\
\text { Major }\end{array}$ & $\begin{array}{l}\text { (Collantes et al., 2015) } \\
\text { (Collantes et al., 2015) } \\
\text { (Collantes et al., 2015) }\end{array}$ \\
\hline
\end{tabular}

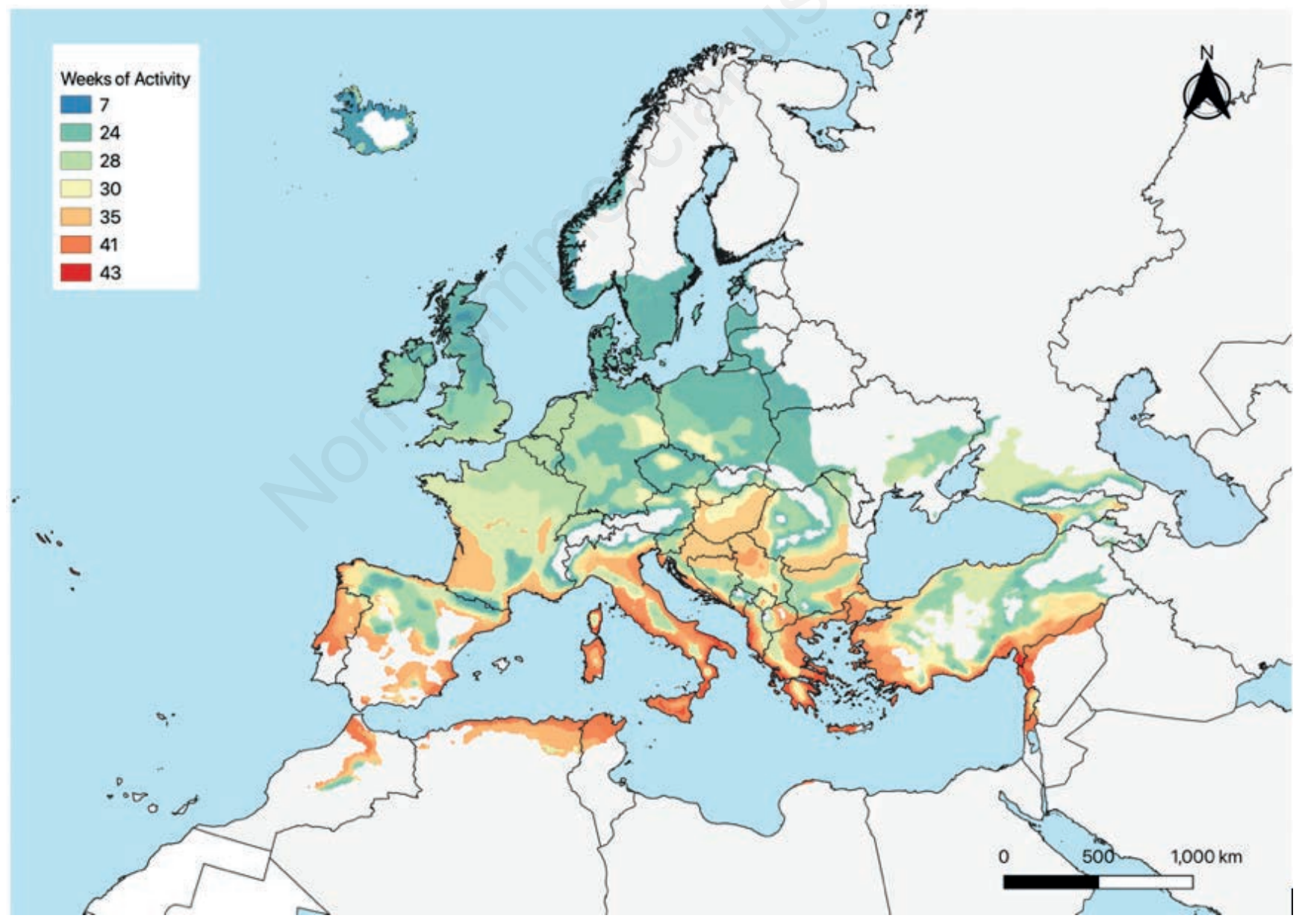

Figure 3. Mean number of weeks during which Aedes albopictus can remain active in the VectorNet area for 2019, obtained after subtracting the modelled end of activity with the modelled start of activity. Colours show the range of activity period, from long (red) to short period (blue). White areas are the masks from temperature and precipitation. Country boundaries are downloaded from Natural Earth. Free vector and raster map data @naturalearthdata.com 
northern latitudes because of the constraint imposed by the mean January isotherm limit.

The spring hatching map can be considered as the first indicator of starting of the vector season. However, this is still different from the emergence of the first adults. The development from larvae L1 to adult during an optimal season with temperatures between $25-30^{\circ} \mathrm{C}$ is about $8-10$ days (Gomes et al., 1995). A laboratory study with Ae. albopictus from La Réunion, France, showed that at these temperatures the mean generation time (the average period between two generations in a population) is about 24-30 days, whilst at a constant temperature of $15^{\circ} \mathrm{C}$, the mean generation time is about 43 days and the development of larvae (L1) until adults is about 35 days (Delatte et al., 2009). At $20^{\circ} \mathrm{C}$, the development from L1 larvae until adults is estimated to last 14 days (Delatte et al., 2009).

As the species breeds in small containers (Stefopoulou et al., 2018), the water temperature can quickly reach high values, even if the air temperature is lower (Kumar et al., 2018). During spring, the temperature conditions often allow a complete development from egg to adult in 2-3 weeks; however, clear field information on the mean duration of a generation time is still missing.

Knowing the timing and size of peak abundance of a vector species, and the factors influencing it, will help decision-makers to guide surveillance and control activities in cost-efficient and effective way. In recent years studies have been performed on seasonal dynamic models at a local scale especially in France (Tran et al., 2013) and Italy (Poletti et al., 2011; Erguler et al., 2016; Manica et al., 2016).

The seasonal abundance patterns predicted by these localscale dynamic models as well as those collected from the reported field studies are also supported by the work done by LiuHelmersson et al. (2016) on climate change and dengue virus transmission in Europe. The authors identified seasonal windows of transmission based on the potential vectorial capacity the species has or would have in Europe. Their results show that in several south-European countries, climatic conditions under current climate change scenarios would favour Ae. albopictus populations, increase their vectorial capacity and allow local dengue virus transmission. The potential for sustained transmission in southern European cities was confirmed by the study of Guzzetta et al. (2016b) for Zika virus.

We observe a good correspondence between the identified abundance peaks and the occurrence of vector-borne disease in the EU (ECDC, 2019c; ECDC, 2020a). The occurrences of dengue and chikungunya in France, with the highest number of autochthonous cases, were reported from July to September (Succo et al., 2016, 2018; Franke et al., 2019). This corresponds well to the two identified peaks in weeks 27 and week 33. In Italy, two significant chikungunya outbreaks were reported in 2007 (July-September) and 2017 (August-November) (Angelini et al., 2007; Rezza et al., 2007; Venturi et al., 2017; Lindh et al., 2019 ), coinciding with the major peaks in vector abundance identified between July and November.

Whilst the seasonality of Ae. albopictus can be determined on a European scale, predicting the peak abundance of $A e$. albopictus at the same scale is challenging. Populations are highly variable across areas and are depending on eco-climatic factors such as local temperature patterns (influencing their life cycle) and the amount and quality of the breeding and resting sites. In turn, the availability of these breeding and resting sites will depend on a high number of factors such as precipitation and proximity to water bodies (Dieng et al., 2012), vegetation and land cover (Vanwambeke et al., 2007; Ferraguti et al., 2016; Steiger et al., 2016), artificial watering and the presence of artificial containers (Guzzetta et al., 2016a).

One of the major issues for an European scale peak abundance models is that micro-environmental conditions in potential habitats are currently not measured in a standardised way and that there is no direct link from the field matching laboratory conditions. The microclima R-package developed by Maclean et al. (2018) provides a possible solution to bridge part of this gap by providing fine-scale estimates of near-ground temperature, however, its scalability to different eco-climatic settings still needs to be validated (Maclean et al., 2018). It is also essential to further study the link between the observed egg/larval stages numbers and female numbers throughout the season such as the study conducted by Manica et al. (2017). Finally, detailed and pivotal data on key life-history traits, such as survival and development, are only available from laboratory experiments but parameters derived solely from such datasets cannot be extrapolated to larger areas (Erguler et al., 2020). Research networks such as VectorBite (Shocket et al., 2019) try to collate these life traits, but currently these databases are still in the setup phase and cannot be used as such.

\section{Conclusions}

The presence of Ae. albopictus in several regions of Europe poses many challenges for the public health authorities and to lesser extent to animal health authorities. At the fringe of its current, yet still expanding, distribution the vector population needs to be controlled as soon as it is detected in a new area to reduce the likelihood of establishment. To achieve this, knowing when vector surveillance should be performed is essential. In contrast, in areas permanently colonised by Ae. albopictus, it is crucial to identify potential spatial and temporal hot spots of abundance in order to prioritise mosquito control interventions.

Within VectorNet, data from literature and field surveys are collected to define vector presence/absence. This provided input for the bi-annual update of the Ae. albopictus distribution maps published online by ECDC. Additionally, abundance data were collected across Europe and within different eco-climatic zones using standardised protocols to feed spatial models and produce updated abundance maps. Risk assessments, which include these abundance data, should focus on the local scale rather than at continental scale because the abundance curve is determined by the local prevailing eco-climatic conditions.

While this paper focused on the egg seasonality and abundance, it is necessary to further promote fundamental and applied research on vectorial capacity and genetic profile of a population and to study the link between the observed egg/larval stages numbers and female numbers to further strengthen initial experiments.

A better knowledge of Ae. albopictus seasonality and abundance can then support public health authorities in their surveillance of arboviruses and their outbreak response activities. 


\section{References}

Allouche O, Tsoar A, Kadmon R, 2006. Assessing the accuracy of species distribution models: prevalence, kappa and the true skill statistic (TSS). J Appl Ecol 43:1223-32.

Angelini R, Finarelli AC, Angelini P, Po C, Petropulacos K, Silvi G, Macini P, Fortuna C, Venturi G, Magurano F, Fiorentini C, 2007. Chikungunya in north-eastern Italy: a summing up of the outbreak. Euro Surveill 12:3313.

Armbruster PA, 2016. Photoperiodic diapause and the establishment of Aedes albopictus (Diptera: Culicidae) in North America. J Med Entomol 53:1013-23.

Baldacchino F, Marcantonio M, Manica M, Marini G, Zorer R, Delucchi L, Arnoldi D, Montarsi F, Capelli G, Rizzoli A, Rosà R, 2017. Mapping of Aedes albopictus abundance at a local scale in Italy. Remote Sens 9:749.

Bonacci T, Mazzei A, Hristova VK, Ahmad MA, 2015. Monitoring of Aedes albopictus (Diptera, Cilicidae) in Calabria, Southern Italy. Int J Sci Eng Res 6:1186-9.

Brady OJ, Johansson MA, Guerra CA, Bhatt S, Golding N, Pigott DM, Delatte H, Grech MG, Leisnham PT, Maciel-de-Freitas R, Styer LM, 2013. Modelling adult Aedes aegypti and Aedes albopictus survival at different temperatures in laboratory and field settings. Parasit Vectors 6:1-2.

Borchers HW, 2019. Pracma: practical numerical math functions. $\mathrm{R}$ package version $2(1)$.

Gomes ADC, Gotlieb LD, de Azevedo Marques C, Bicudo de Paula M, Marques GR, 1995. Duration of larval and pupal development stages of Aedes albopictus in natural and artificial containers. Rev Saude Publica 29:15-9.

Caminade C, Medlock JM, Ducheyne E, McIntyre KM, Leach S, Baylis M, Morse AP, 2012. Suitability of European climate for the Asian tiger mosquito Aedes albopictus: recent trends and future scenarios. J R Soc Interface 9:2708-17.

CCCS (Copernicus Climate Change Service), 2019. ERA5-Land hourly data from 2001 to present. Available from: https://doi.org/10.24381/CDS.E2161BAC

Collantes F, Delgado JA, Alarcón-Elbal PM, Delacour S, Lucientes J, 2014. First confirmed outdoor winter reproductive activity of Asian tiger mosquito (Aedes albopictus) in Europe. An Inst Biol 36:71-6.

Collantes F, Delacour S, Alarcón-Elbal PM, Ruiz-Arrondo I, Delgado JA, Torrell-Sorio A, Bengoa M, Eritja R, Miranda MÁ, Molina R, Lucientes J, 2015. Review of ten-years presence of Aedes albopictus in Spain 2004-2014: known distribution and public health concerns. Parasit Vectors 8:1-1.

Cunze S, Kochmann J, Koch LK, Klimpel S, 2016. Aedes albopictus and its environmental limits in Europe. PLoS One 11:e0162116.

Delatte H, Gimonneau G, Triboire A, Fontenille D, 2009. Influence of temperature on immature development, survival, longevity, fecundity, and gonotrophic cycles of Aedes albopictus, vector of chikungunya and dengue in the Indian Ocean. J Med Entomol 46:33-41.

Dieng H, Rahman GMS, Hassan AA, Salmah MRC, Satho T, Miake F, Boots M, Sazaly A, 2012. The effects of simulated rainfall on immature population dynamics of Aedes albopictus and female oviposition Int J Biometeorol 56:113-20.

Erguler K, Smith-Unna SE, Waldock J, Proestos Y, Christophides GK, Lelieveld J, Parham PE, 2016. Large-Scale modelling of the environmentally-driven population dynamics of temper- ate Aedes albopictus (Skuse). PLoS One 11:e0149282.

Erguler K, Demirok M, Gunay F, Petrić M, Kavran M, Petrić D, Alten B, 2020. Model-based design and analysis of life table experiments for insect vectors. BioRxiv [Epub ahead of print].

Erickson RA, Presley SM, Allen LJS, Long KR, Cox SB, 2010. A stage-structured, Aedes albopictus population model. Ecol Model 221:1273-82.

Eritja R, Escosa R, Lucientes J, Marques E, Roiz D, Ruiz S, 2005. Worldwide invasion of vector mosquitoes: present European distribution and challenges for Spain. Biol Invasions 7:87-97.

ECDC (European Centre for Disease Prevention and Control), 2009. Development of Aedes albopictus risk maps. Technical report: ECDC, 45 pp. Available from: https://www.ecdc. europa.eu/en/publications-data/development-aedes-albopictus-risk-maps Accessed: 26 January 2021.

ECDC (European Centre for Disease Prevention and Control), 2017. Clusters of autochthonous chikungunya cases in France. Rapid risk assessment, ECDC: 10 pp. Available from: 14-08-2017-RRA-Chikungunya-France Accessed: 4 January 2021.

ECDC (European Centre for Disease Prevention and Control), 2019a. Aedes albopictus - current known distribution: August 2019. Stockholm: ECDC. Available from: https://www. ecdc.europa.eu/en/publications-data/aedes-albopictus-current-known-distribution-august-2019 Accessed: 26 January 2021.

ECDC (European Centre for Disease Prevention and Control), 2019b. Autochthonous cases of dengue in Spain and France. Rapid risk assessment, ECDC: 8 pp. Available from: https://www.ecdc.europa.eu/sites/default/files/documents/RR A-dengue-in-Spain-France_1Oct2019.pdf Accessed: 4 January 2021.

ECDC (European Centre for Disease Prevention and Control), 2019c. Zika virus disease in Var department, France. Rapid risk assessment, ECDC: 8 pp. Available from: https://www. ecdc.europa.eu/en/publications-data/rapid-risk-assessmentzika-virus-disease-var-department-france Accessed: 26 January 2021.

ECDC (European Centre for Disease Prevention and Control), 2020a. Autochthonous transmission of dengue virus in EU/EEA, 2010-2020. Surveillance and disease data, ECDC. Available from: https://www.ecdc.europa.eu/sites/default/ files/ documents/RRA-dengue-in-Spain-France_1Oct2019. pdf Accessed: 19 January 2021.

ECDC (European Centre for Disease Prevention and Control), 2020b. Aedes albopictus - current known distribution. ECDC. Available from: https:/www.ecdc.europa.eu/en/publicationsdata/aedes-albopictus-current-known-distribution-may-2020 Accessed: 26 January 2021.

ECDC \& EFSA (European Centre for Disease Prevention and Control and European Food Safety Authority), 2018a. Field sampling methods for mosquitoes, sandflies, biting midges and ticks - VectorNet project 2014-2018. ECDC and EFSA: 45 pp. Available from: https://www.ecdc.europa. eu/sites/default/ files/documents/Vector-sampling-field-protocol-2018.pdf Accessed: 12 February 2021.

ECDC \& EFSA (European Centre for Disease Prevention and Control and European Food Safety Authority), 2018b. The importance of vector abundance and seasonality - Results 
from an expert consultation. ECDC and EFSA: $48 \mathrm{pp}$. Available from: https://www.ecdc.europa.eu/sites/ default/files/ documents/vector-abundance-and-seasonality. pdf Accessed: 12 February 2021.

Ferraguti M, Martínez-de La Puente J, Roiz D, Ruiz S, Soriguer R, Figuerola J, 2016. Effects of landscape anthropization on mosquito community composition and abundance. Sci Rep 6:1-9.

Flacio E, Engeler L, Tonolla M, Müller P, 2016. Spread and establishment of Aedes albopictus in southern Switzerland between 2003 and 2014: An analysis of oviposition data and weather conditions. Parasit Vectors 9:304.

Focks DA, Linda SB, Craig Jnr GB, Hawley WA, Pumpuni CB, 1994. Aedes albopictus (Diptera: Culicidae): A statistical model of the role of temperature, photoperiod, and geography in the induction of egg diapause. J Med Entomol 31:278-86.

Franke F, Giron S, Cochet A, Jeannin C, Leparc-Goffart I, de Valk H, Jourdain F, de Lamballerie X, L'Ambert G, Paty MC, 2019. Autochthonous chikungunya and dengue fever outbreak in Mainland France, 2010-2018. Eur J Public Health 29:ckz186-628.

Gatt P, Schaffner F, Cassar LF, 2010. Aedes (Stegomyia) albopictus (Skuse) (Diptera: Culicidae) in Malta - the first winter. Eur Mosq Bull 28:225-9.

Ghasemi A, Zahediasl S, 2012. Normality tests for statistical analysis: a guide for non-statisticians. Int J Endocrinol Metab 10:486.

Giatropoulos A, Emmanouel N, Koliopoulos G, Michaelakis A, 2012. A study on distribution and seasonal abundance of Aedes albopictus (Diptera: Culicidae) population in Athens, Greece. J Med Entomol 49:262-9.

Giron S, Franke F, Decoppet A, Cadiou B, Travaglini T, Thirion L, Durand G, Jeannin C, L'Ambert G, Grard G, Noël H, Fournet N, Auzet-Caillaud M, Zandotti C, Aboukaïs S, Chaud P, Guedj S, Hamouda L, Naudot X, Ovize A, Lazarus C, de Valk H, Paty M-C, Leparc-Goffart I, 2019. Vectorborne transmission of Zika virus in Europe, southern France, August 2019. Euro Surveill 24:pii=1900655.

Guzzetta G, Montarsi F, Baldacchino FA, Metz M, Capelli G, Rizzoli A, Pugliese A, Rosà R, Poletti P, Merler S, 2016a. Potential risk of dengue and chikungunya outbreaks in northern Italy based on a population model of Aedes albopictus (Diptera: Culicidae). PLoS Negl Trop Dis 10:e0004762.

Guzzetta G, Poletti P, Montarsi F, Baldacchino F, Capelli G, Rizzoli A, Rosa R, Merler S, 2016b. Assessing the potential risk of Zika virus epidemics in temperate areas with established Aedes albopictus populations. Euro Surveill 21: pii $=30199$.

Hawley WA, 1988. The biology of Aedes albopictus. J Am Mosq Control Assoc 4:1-39.

Hijmans RJ, 2019. meteor: Meteorological Data Manipulation R package version 0 (3).

Hylton AR, 1969. Studies on longevity of adult Eretmapodites chrysogaster, Aedes togoi and Aedes (Stegomyia) albopictus females (Diptera: Culicidae). J Med Entomol 6:147-149.

Kendon M, McCarthy M, Jevrejeva S, Matthews A, Legg T, 2020. State of the UK climate 2018. Int J Climatol 39:1-55.

Khan SU, Ogden NH, Fazil AA, Gachon PH, Dueymes GU, Greer AL, Ng V, 2020. Current and Projected Distributions of Aedes aegypti and Ae. albopictus in Canada and the US. Environ Health Perspect 128:057007.
Knudsen AB, Romi R, Majori G, 1996. Occurrence and spread in Italy of Aedes albopictus, with implications for its introduction into other parts of Europe. J Am Mosq Control Assoc 12:177-83.

Kobayashi M, Nihei N, Kurihara T, 2002. Analysis of northern distribution of Aedes albopictus (Diptera: Culicidae) in Japan by geographical information system. J Med Entomol 39:4-11.

Komagata O, Higa Y, Muto A, Hirabayashi K, Yoshida M, Sato T, Nihei N, Sawabe K, Kobayashi M, 2017. Predicting the start of the Aedes albopictus (Diptera: Culicidae) female adult biting season using the spring temperature in Japan. J Med Entomol 54:1519-24.

Kuhlisch C, Kampen H, Walther D, 2018. The Asian tiger mosquito Aedes albopictus (Diptera: Culicidae) in Central Germany: Surveillance in its northernmost distribution area. Acta Trop 188:78-85.

Kumar G, Pande V, Pasi S, Ojha VP, Dhiman RC, 2018. Air versus water temperature of aquatic habitats in Delhi: implications for transmission dynamics of Aedes aegypti. Geospat Health 13:707.

Lacour G, Chanaud L, L'Ambert G, Hance T, 2015. Seasonal synchronization of diapause phases in Aedes albopictus (Diptera: Culicidae). PLoS One 10:e0145311.

Lacour G, 2016. Eco-physiological mechanisms and adaptive value of egg diapause in the invasive mosquito Aedes albopictus (Diptera, Culicidae). Thesis. University of Louvain-La-Neuve, 229 pp. Available from: https://dial.uclouvain. be/pr/boreal/object/boreal:175328. Accessed: 12 February 2021.

Lajeunesse MJ, 2016. Facilitating systematic reviews, data extraction, and meta-analysis with the metagear package for R. Methods Ecol Evol 7:323-30.

Lindh E, Argentini C, Remoli ME, Fortuna C, Faggioni G, Benedetti E, Amendola A, Marsili G, Lista F, Rezza G, Venturi G, 2019. The Italian 2017 outbreak Chikungunya virus belongs to an emerging Aedes albopictus-adapted virus cluster introduced from the Indian subcontinent. Open Forum Infect Dis 6:ofy321.

Liu-Helmersson J, Quam M, Wilder-Smith A, Stenlund H, Ebi K, Massad E, Rocklöv J, 2016. Climate change and Aedes vectors: 21st Century projections for dengue transmission in Europe. EBioMedicine 7:267-77.

Maclean IM, Mosedale JR, Bennie JJ, 2018. Microclima: An r package for modelling meso and microclimate. Methods Ecol Evol 10:280-90.

Manica M, Filipponi F, D'Alessandro A, Screti A, Neteler M, Rosà R, Solimini A, Della Torre A, Caputo B, 2016. Spatial and temporal hot spots of Aedes albopictus abundance inside and outside a south European metropolitan area. PLoS Negl Trop Dis 10:e0004758.

Manica M, Rosa R, Della Torre A, Caputo B, 2017. From eggs to bites: do ovitrap data provide reliable estimates of Aedes albopictus biting females? PeerJ 5:e2998.

McKenzie BA, Wilson AE, Zohdy S, 2019. Aedes albopictus is a competent vector of Zika virus: A meta-analysis. PLoS One 14:e216794.

Medlock JM, Avenell D, Barrass I, Leach S, 2006. Analysis of the potential for survival and seasonal activity of Aedes albopictus (Diptera: Culicidae) in the United Kingdom. J Vector Ecol 31:292-304.

Medlock JM, Hansford KM, Versteirt V, Cull B, Kampen H, 
Fontenille D, Hendrickx G, Zeller H, Van Bortel W, Schaffner F, 2015. An entomological review of invasive mosquitoes in Europe. B Entomol Res 105:637.

Metelmann S, Caminade C, Jones AE, Medlock JM, Baylis M, Morse AP, 2019. The UK's suitability for Aedes albopictus in current and future climates. J R Soc Interface 16:20180761.

Mogi M, Tuno N, 2014. Impact of climate change on the distribution of Aedes albopictus (Diptera: Culicidae) in northern Japan: retrospective analyses. J Medl Entomol 51:572-9.

Nawrocki S, Hawley W, 1987. Estimation of the northern limits of distribution of Aedes albopictus in North America. J Am Mosq Control Assoc 3:314-7.

Neteler M, Metz M, Rocchini D, Rizzoli A, Flacio E, Engeler L, Guidi V, Lüthy P, Tonolla M, 2013. Is Switzerland suitable for the invasion of Aedes albopictus?. PLoS One 8:e82090.

Ogden NH, Milka R, Caminade C, Gachon P, 2014. Recent and projected future climatic suitability of North America for the Asian tiger mosquito Aedes albopictus. Parasit \& Vectors $1: 1-4$.

Pasquali S, Mariani L, Calvitti M, Moretti R, Ponti L, Chiari M, Sperandio G, Gilioli G, 2020. Development and calibration of a model for the potential establishment and impact of Aedes albopictus in Europe. Acta Trop 202:105228.

Petrić M, Lalić B, Pajović I, Micev S, Đurđević V, Petrić D, 2018. Expected changes of Montenegrin climate, impact on the establishment and spread of the Asian tiger mosquito (Aedes albopictus), and validation of the model and modelbased field sampling. Atmosphere 9:453.

Poletti P, Messeri G, Ajelli M, Vallorani R, Rizzo C, Merler S, 2011. Transmission potential of chikungunya virus and control measures: The case of Italy. PLoS One 6:e18860.

Proestos Y, Christophides GK, Ergüler K, Tanarhte M, Waldock J, Lelieveld J, 2015. Present and future projections of habitat suitability of the Asian tiger mosquito, a vector of viral pathogens, from global climate simulation. Philos Trans R Soc 370:20130554.

Rezza G, Nicoletti L, Angelini R, Romi R, Finarelli AC, Panning M, Cordioli P, Fortuna C, Boros S, Magurano F, Silvi G, 2007. Infection with chikungunya virus in Italy: an outbreak in a temperate region. Lancet 370:1840-6.

Roiz D, Rosà R, Arnoldi D, Rizzoli A, 2010. Effects of temperature and rainfall on the activity and dynamics of host-seeking Aedes albopictus females in northern Italy. Vector Borne Zoonotic Dis 10:811-6.

Roiz D, Neteler M, Castellani C, Arnoldi D, Rizzoli A, 2011. Climatic factors driving invasion of the tiger mosquito (Aedes albopictus) into new areas of Trentino, northern Italy. PLoS One 6:e14800.

Schaffner F, Medlock JM, Van Bortel AW, 2013. Public health significance of invasive mosquitoes in Europe. Clin Microbiol Infect 19:685-92.

Scheiner SM, 1993. Genetics and evolution of phenotypic plasticity. Annu Rev Ecol Evol Syst 24:35-68.

Sherpa S, Guéguen M, Renaud J, Blum MG, Gaude T, Laporte F, Akiner M, Alten B, Aranda C, Barre-Cardi H, Bellini R, 2019. Predicting the success of an invader: niche shift versus niche conservatism. Ecol Evol 9:12658-75.

Shocket MS, Watts M, Windram F, Rund S, Cator L, Johnson LR, Pawar S, 2019. VectorByte: Public databases of vector abundances and vector performance traits. Entom ESA 2019. Available from: https://www.vectorbyte.org/ Accessed: 07
April 2021.

Stefopoulou A, Balatsos G, Petraki A, LaDeau SL, Papachristos D, Michaelakis A, 2018. Reducing Aedes albopictus breeding sites through education: A study in urban area. PLoS One 13:0202451.

Steiger DBM, Ritchie SA, Laurance SG, 2016. Mosquito communities and disease risk influenced by land use change and seasonality in the Australian tropics. Parasit Vectors 9:387.

Succo T, Leparc-Goffart I, Ferré JB, Roiz D, Broche B, Maquart M, Noel H, Catelinois O, Entezam F, Caire D, Jourdain F, 2016. Autochthonous dengue outbreak in Nîmes, south of France, July to September 2015. Euro Surveill 21:30240.

Succo T, Noël H, Nikolay B, Maquart M, Cochet A, LeparcGoffart I, Catelinois O, Salje H, Pelat C, de Crouy-Chanel P, de Valk H, 2018. Dengue serosurvey after a 2-month long outbreak in Nîmes, France, 2015: was there more than met the eye? Euro Surveill 23:1700482.

Suter TT, Flacio E, Feijoó Fariña B, Engeler L, Tonolla M, Regis LN, De Melo Santos MAV, Müller P, 2016. Surveillance and control of Aedes albopictus in the Swiss-Italian border region: Differences in egg densities between intervention and non-intervention areas. PLoS Negl Trop Dis 10:e004315.

Swanson J, Lancaster M, Anderson J, Crandell M, Haramis L, Grimstad P, Kitron U, 2000. Overwintering and establishment of Aedes albopictus (Diptera: Culicidae) in an urban La Crosse virus enzootic site in Illinois. J Medical Entomol 37:454-60.

Takumi K, Scholte EJ, Braks M, Reusken C, Avenell D, Medlock JM, 2009. Introduction, scenarios for establishment and seasonal activity of Aedes albopictus in The Netherlands. Vector Borne Zoonotic Dis 9:191-6.

Tippelt L, Werner D, Kampen H, 2020. Low temperature tolerance of three Aedes albopictus strains (Diptera: Culicidae) under constant and fluctuating temperature scenarios. Parasit Vectors 13:1-2.

Toma L, Severini F, Di Luca M, Bella A, Romi R, 2003. Seasonal patterns of oviposition and egg hatching rate of Aedes albopictus in Rome. J Am Mosq Control Assoc 19:19-22.

Tran A, L'Ambert G, Lacour G, Benoît R, Demarchi M, Cros M, Cailly P, Aubry-Kientz M, Balenghien T, Ezanno P, 2013. A rainfall- and temperature-driven abundance model for Aedes albopictus populations. Int J Environ Res Public Health 10:1698-719.

Tsunoda T, Chaves LF, Nguyen GT, Nguyen YT, Takagi M, 2015. Winter Activity and Diapause of Aedes albopictus (Diptera: Culicidae) in Hanoi, Northern Vietnam. J Med Entomol 52:1203-12.

Vanwambeke SO, Somboon P, Harbach RE, Isenstadt M, Lambin EF, Walton C, Butlin RK, 2007. Landscape and land cover factors influence the presence of Aedes and Anopheles larvae. J Med Entomol 44:133-44.

Venturi G, Di Luca M, Fortuna C, Remoli ME, Riccardo F, Severini F, Toma L, Del Manso M, Benedetti E, Caporali MG, Amendola A, 2017. Detection of a chikungunya outbreak in Central Italy, August to September 2017. Euro Surveill 22:17-00646.

Waldock J, Chandra NL, Lelieveld J, Proestos Y, Michael E, Christophides G, Parham PE, 2013. The role of environmental variables on Aedes albopictus biology and chikungunya epidemiology. Pathog Glob Health 107:224-41.

Wint W, Petric D, Bortel W, Alexander N, Schaffner F, 2020. 
RVF vector spatial distribution models: vector abundance. EFSA Support Publ 17:1847E.

Wu F, Liu Q, Lu L, Wang J, Song X, Ren D, 2011. Distribution of Aedes albopictus (Diptera: Culicidae) in northwestern China. Vector Borne Zoonotic Dis 11:1181-6.

Xia D, Guo X, Hu T, Li L, Teng PY, Yin QQ, Luo L, Xie T, Wei YH, Yang Q, Li SK, 2018. Photoperiodic diapause in a sub- tropical population of Aedes albopictus in Guangzhou, China: optimized field-laboratory-based study and statistical models for comprehensive characterization. Infect Dis Poverty 7:1-3.

Žitko T, Merdić E, 2014. Seasonal and spatial oviposition activity of Aedes albopictus (Diptera: Culicidae) in Adriatic Croatia. J Med Entomol 51:760-8. 